\title{
PENERAPAN TEKNOLOGI PENDIDIKAN DI LEMBAGA PENDIDIKAN NONFORMAL
}

\author{
Fathia Fairuza Hanum \\ email: fathiafairuza.hanum@gmail.com \\ Tutor PKBM Negeri 23 Jakarta \\ Jalan K.H Mas Mansyur No. 92 Jakarta Pusat \\ Suprayekti \\ email: ssuprayekti@gmail.com \\ Program Studi Teknologi Pendidikan, Universitas Negeri Jakarta \\ Jalan Rawamangun Muka, Jakarta Timur
}

\begin{abstract}
Abstrak: Teknologi pendidikan sebagai disiplin ilmu memiliki kontribusi dalam memfasilitasi pemecahan masalah belajar dan dapat diaplikasikan di pendidikan nonformal sebagai bagian dari pendidikan masyarakat. Karenanya diperlukan kajian mengenai kawasan teknologi pendidikan apa saja yang telah diterapkan. Hal ini mengingat kawasan kajian pada teknologi pendidikan yang turut berubah dari waktu ke waktu. Penelitian ini bertujuan untuk mengidentifikasi penerapan kawasan teknologi pendidikan yang ada di lembaga pendidikan nonformal yang terdiri dari kawasan penciptaan, penggunaan, pengelolaan dan evaluasi. Penelitian ini termasuk dalam penelitian evaluatif dengan pendekatan studi kasus. Pengumpulan data dilakukan dengan lembar angket, pedoman wawancara dan dokumentasi. Penelitian ini dilakukan di LPBB Solusi Kayumanis dan PKBM Negeri 23 Jakarta pada bulan Juni sampai Oktober 2018. Hasil penelitian secara umum menunjukkan bahwa seluruh kawasan teknologi pendidikan telah diterapkan di kedua lembaga pendidikan nonformal. Beberapa indikator pada keempat kawasan sudah diterapkan dengan sangat baik karena lembaga telah memiliki aturan dan regulasi yang baik dalam melakukan penerapan. Ada beberapa indikator yang sudah diterapkan dengan baik tapi masih sederhana dan terbatas. Namun ada juga beberapa indikator yang belum diterapkan. Berdasarkan hasil penelitian maka direkomendasikan agar indikator yang telah diterapkan dengan sangat baik dapat terus dipertahankan. Sedangkan indikator yang belum diterapkan dan penerapannya masih sederhana, dapat membuka kerja sama dengan para teknolog pendidikan.
\end{abstract}

Kata-kata kunci: Implementasi, Lembaga Pendidikan Nonformal, Penelitian Evaluatif, Teknologi Pendidikan

\section{IMPLEMENTATION OF EDUCATIONAL TECHNOLOGY IN NON- FORMAL EDUCATION INSTITUTION}

\begin{abstract}
Educational technology as a scientific discipline contributes to facilitating learning problem solving and can be applied in non-formal education as part of public education. Therefore a study on educational technology areas that have been implemented is needed to be conducted. This is considering the area of study on educational technology that also changes over time. The purpose of this study is to identify the implementation of educational technology areas that have been applied in non-formal education institutions that consists of the area of creating, using, managing and evaluating. This study is an evaluative research with a case study approach. To collect the data, this study used a questionnaire interview, and documentation. This study was conducted at LPBB Solusi Kayumanis and PKBM Negeri 23 Jakarta from June to October 2018. Generally, the results of the study indicated that the entire educational technology area has been applied in both non-formal educational institutions. Some indicators from the four areas have been implemented very well because the institutions have good rules and regulations. There are also several indicators that have been implemented well, but the implementation is still simple and limited. Further, there are also some indicators that have not been implemented. Based on the result, it was recommended to both institutions to maintain the indicators that have been implemented very well. Meanwhile, indicators that have not been implemented or their implementation are still simple,
\end{abstract}


Penerapan Teknologi Pendidikan...

both institutions can collaborate with educational technologists to give contribution.

Keywords: Educational Technology, Evaluative Research, Implementation, Nonformal Education Institutions

\section{PENDAHULUAN}

Teknologi Pendidikan adalah teori dan praktik dalam desain, pengembangan, pemanfaatan, pengelolaan, serta evaluasi proses dan sumber untuk belajar (AECT - Association for Educational Communications and Technology, 1994). Menurut AECT tahun 2004 Teknologi Pendidikan adalah studi dan praktik etis untuk memfasilitasi belajar dan meningkatkan kinerja dengan menciptakan, menggunakan, dan mengelola proses dan sumber daya teknologi yang sesuai. Teknologi pendidikan memiliki objek formal "belajar", belajar merupakan aktivitas mental yang dilakukan oleh tiap individu, baik di kelompok, organisasi atau secara perorangan. Belajar tidak hanya berlangsung dalam lingkup sekolah ataupun pelatihan, tetapi juga pada organisasi, misalnya keluarga, masyarakat, dunia usaha, bahkan pemerintahan. Belajar dapat dilakukan dimana saja, kapan saja dan pada siapa saja, mengenai apa saja, dengan cara dan sumber daya apa saja yang sesuai dengan kondisi dan kebutuhan (Miarso, 2004). Teknologi pendidikan berupaya memacu (merangsang) dan memicu (menumbuhkan) belajar melalui pemanfaatan teknologi dalam rangka mencapai tujuan pembelajaran dan berupaya membantu memecahkan masalah-masalah yang muncul dalam pendidikan secara umum.

Salah satu masalah dalam konteks pendidikan dewasa ini adalah terbatasnya kemampuan jalur pendidikan formal (lembaga pendidikan formal) untuk memberikan pelayanan pendidikan kepada masyarakat secara menyeluruh dan maksimal. Dalam upaya memenuhi kebutuhan masyarakat dalam hal pendidikan, maka jalur Pendidikan Luar Sekolah (PLS) atau dikenal dengan pendidikan nonformal dianggap mampu memberikan kontribusi yang sangat besar terhadap sistem pendidikan nasional. Satuan pendidikan pada lembaga nonformal berfungsi dalam mengembangkan potensi peserta didik dengan penekanan pada penguasaaan pengetahuan, keterampilan fungsional serta pengembangan sikap dan kepribadian profesional. Selain itu dalam Peraturan Pemerintah Republik Indonesia No. 73 Tahun 1991, pendidikan luar sekolah/pendidikan nonformal bertujuan untuk: (1) melayani warga belajar supaya dapat tumbuh dan berkembang sedini mungkin dan sepanjang hayatnya guna meningkatkan martabat dan mutu kehidupannya, (2) membawa warga belajar agar memiliki pengetahuan, keterampilan dan sikap mental yang diperlukan untuk mengembangkan diri, bekerja mencari nafkah atau melanjutkan ke tingkat dan/atau jenjang pendidikan yang lebih tinggi, dan (3) memenuhi kebutuhan belajar masyarakat yang tidak dapat dipenuhi dalam jalur pendidikan sekolah.

Dalam upaya untuk mencapai tujuan pembelajaran secara umum dan kebutuhan masyarakat akan layanan pendidikan serta keterampilan dapat terakomodasi, teknologi pendidikan sebagai disiplin ilmu dan bidang studi yang dapat memfasilitasi pemecahan masalah belajar pada manusia dapat berkontribusi dan diaplikasikan pada pendidikan nonformal. Teknologi pendidikan beserta kawasan dan poduknya dapat diterapkan pada pendidikan nonformal untuk memfasilitasi belajar peserta didik dalam rangka mencapai tujuan dan fungsi dari pendidikan nonformal sebagai bagian dari pendidikan berbasis masyarakat. Perubahan konsepsi teknologi pendidikan yang dikemukakan oleh AECT dari tahun ke tahun membuat kawasan kajian teknologi pendidikan juga turut berubah, yang berdampak pada semakin meluasnya kontribusi teknologi pendidikan. Kawasan kajian pada bidang teknologi pendidikan berdasarkan definisi AECT tahun 1994 dan 2004 yakni: kawasan penciptaan, kawasan penggunaan, kawasan pengelolaan, dan kawasan evaluasi.

Pertama, pada kawasan penciptaan ada dua istilah yakni desain (design) dan pengembangan (development) dimana istilah tersebut mencakup aktivitas analisis, refleksi kritis, sampai pengembangan gagasan atau ide, desain atau rancangan, hingga menghasilkan produk baik berupa perangkatperangkat material pembelajaran, sistem, tata aturan/ regulasi, dan kebijakan yang menunjang penggunaan dan pengelolaan produk-produk teknologi pendidikan. Kedua, pada kawasan penggunaan, aktivitas pada domain penggunaan meliputi penggunaan produk teknologi pendidikan yang terjadi dalam tiap aktivitas pembelajaran baik informal, nonformal maupun formal. Terbagi menjadi dua tahap yakni tahap memilah dan memilih produk teknologi pendidikan yang tepat dan tahap menggunakan produk teknologi pendidikan yang 
tepat dengan cara yang tepat.

Ketiga, pada kawasan pengelolaan, teknologi pendidikan mengalami perluasan konsep mengenai hal-hal apa saja yang dikelola. Berdasarkan definisi AECT 1994 (dalam Seels, 1994) dan definisi AECT 2004 (dalam Januszweski, 2008) sasaran pengelolaan meliputi pengelolaan proyek, pengelolaan sistem penyampaian, pengelolaan informasi, pengelolaan sumber-sumber belajar, pengelolaan personel dan pengelolaan program. Keempat, pada definisi AECT 1994 (dalam Seels, 1994) terdapat empat domain pada kawasan evaluasi yakni: analisis masalah, pengukuran acuan patokan, penilaian formatif dan penilaian sumatif. Sasaran evaluasinya antara lain program, proyek dan produk teknologi pendidikan. Sementara itu, pada definisi resmi AECT 2004 aktivitas evaluasi menjadi bagian integral dari semua aktivitas teknologi pendidikan lainnya.

Sudah banyak penelitian - penelitian yang menjelaskan beberapa bentuk penerapan teknologi pendidikan beserta kawasannya di berbagai jenis lembaga pendidikan nonformal. Untuk kawasan penciptaan, penelitian yang dilakukan oleh Tohani (2011) menghasilkan model program pendidikan kecakapan hidup yang mampu memenuhi perannya dalam pengembangan pendidikan nonformal dalam rangka mengurangi kemiskinan di pedesaan. Pengembangan model pendidikan kecakapan hidup dilakukan dalam dua tahap yaitu: (1) kegiatan pengkajian mengenai kebutuhan kecakapan hidup yang dialami oleh kelompok sasaran, dan (2) mendasarkan pada temuan tersebut, dilakukan pengembangan model pendidikan kecakapan. Penelitian serupa dilakukan oleh Irwan, dkk (2016) yang mengembangkan strategi peningkatan peran PKBM dalam meningkatkan kecakapan hidup masyarakat melalui pendampingan berbasis kearifan lokal di PKBM Provinsi Banten. Hasil penelitian menghasilkan perencanaan yang melibatkan warga belajar dan tokoh masyarakat didalamnya terdapat identifikasi kebutuhan dan masalah, membuat desain program, menyosialisasikan program ke masyarakat, pembentukan struktur kepanitiaan dan pembagian tugas serta menentukan tindak lanjut program.

Penelitian lain dilakukan oleh Sayori (2015) yang melakukan pengembangan manajemen administrasi PKBM di Kabupaten Manokwari, sehingga pengelola atau ketua PKBM mampu menerapkan fungsifungsi manajemen seperti: proses perencanaan, pengorganisasian, pengkoordinasian dan pengawasan dalam bentuk pembinaan yang disertai evaluasi sehingga apa yang menjadi tujuan lembaga dapat tercapai dan berjalan efektif dan efisien.

Untuk kawasan penggunaan, penelitian yang dilakukan oleh Bonastar (2015) dan Nawipa (2018) berfokus pada model pelatihan sebagai bentuk pemberdayaan pada pendidikan nonformal. Bonastar (2015) menggunakan model pelatihan budidaya lele di desa Kreteranggon Kabupaten Lamongan untuk menumbuhkan motivasi berwirausaha pemuda karang taruna. Penelitian tersebut menghasilkan pelatihan budidaya ikan lele selama selama 2 bulan membuat peserta didik mempunyai motivasi tinggi untuk berwirausaha dan sudah dapat menerapkan hasil dari model pelatihan. Nawipa (2018) melakukan penelitian tentang model pelatihan dan pemberdayaan berbasis asrama yang dilakukan oleh Yayasan Pelayanan Antar Budaya melalui Training Indonesians For Transition to Institutional "TITIP" di Tanah Papua. Penelitian yang dilakukan mengindikasikan perbandingan antara pre-test dan post-test telah menunjukkan bahwa adanya peningkatan diri (memiliki life skill) dari proses pelatihan dan pemberdayaan yang dilakukan.

Penelitian yang dilakukan oleh Hari (2015) dan Rosfita (2017) berfokus pada penggunaan metode pembelajaran di lembaga pendidikan nonformal. Hasil penelitian yang dilakukan oleh Hari (2015) adalah interaksi yang terjadi di TPQ Al-lttihad berlangsung secara interaktif karena metode pembelajaran yang digunakan di TPQ Al-Ittihad sangat bervariasi, yaitu meliputi metode privat, klasikal, BCM (belajar, cerita, menyanyi). Selain itu metode yang digunakan menggunakan berbagai pendekatan antara lain pendekatan fungsional, pendekatan qolbu, dan pendekatan keteladanan. Hasil penelitian Rosfita (2017) menunjukkan bahwa penerapan metode karyawisata pada mata pelajaran sejarah di SMP Homeschooling Primagama sudah mengandung penerapan unsur-unsur ASSURE yang membuat peserta didik menjadi lebih memahami materi yang dipelajari.

Untuk kawasan pengelolaan, penelitian yang dilakukan oleh Sari dkk (2012) dan Fatiannisa (2017) berfokus pada pengelolaan program di lembaga pendidikan nonformal. Sari dkk (2012) mengidentifikasi pengelolaan program pada lembaga kursus musik sedangkan Fatiannisa (2017) mengidentifikasi pengelolaan program pada lembaga Pusat Pendidikan Bahasa Inggris Simpel dan Cepat (SPEC) Borobudur yang meliputi perencanaan (jangka pendek, menengah dan panjang), pelaksanaan (metode dan teori yang digunakan), evaluasi (standar penilaian dan output) dan faktor yang mempengaruhi pogram. Untuk kawasan evaluasi, Jelita (2015) melakukan evaluasi program 
di Panti Asuhan Uswatun Hasanah Samarinda untuk mengetahui tingkat efektivitas pelaksanaan program yang dilihat dari (1) evaluasi input, (2) evaluasi proses, (3) evaluasi hasil, dan (4) evaluasi dampak.

Penelitian-penelitian yang telah dipaparkan di atas menunjukkan bentuk-bentuk penerapan teknologi pendidikan di berbagai lembaga pendidikan nonformal. Namun penelitian-penelitian tersebut baru terfokus pada 1 bentuk penerapan dan 1 jenis kawasan di sebuah lembaga. Belum ada penelitian yang mengidentifikasi bentuk penerapan teknologi pendidikan secara menyeluruh di sebuah lembaga berdasarkan keempat kawasan kajian. Selain itu peneliti ingin memperluas cakupan hasil penelitian mengenai bentuk penerapan disiplin ilmu teknologi pendidikan di lembaga pendidikan. Karena pada tahun 2017 peneliti telah mengidentifikasi penerapan teknologi pendidikan di lembaga pendidikan formal tingkat Sekolah Dasar (SD).

Berdasarkan latar belakang tersebut maka peneliti melakukan identifikasi menyeluruh mengenai penerapan teknologi pendidikan berdasarkan 4 kawasan teknologi pendidikan di 2 lembaga pendidikan nonformal. Teknologi pendidikan diharapkan mampu berkontribusi nyata dalam rangka memfasilitasi belajar di lembaga pendidikan nonformal dan mewujudkan pendidikan berbasis masyarakat. Penelitian ini diharapkan mampu menambah khasanah pengetahuan tentang bentuk konkret penerapan teknologi pendidikan di lembaga pendidikan sebagai suatu disiplin ilmu, dan dapat mendorong para teknolog pendidikan ataupun peneliti di tingkat Strata 1 (S1) melakukan kerja sama dengan lembagalembaga pendidikan nonformal untuk menerapkan teknologi pendidikan beserta kawasannya ataupun menindaklanjuti hasil dari penelitian ini.

\section{METODE PENELITIAN}

Penelitian ini termasuk dalam jenis penelitian evaluatif dengan metode studi kasus. Penelitian evaluatif menurut Arikunto (2006) adalah sebuah kegiatan pengumpulan data atau informasi, untuk dibandingkan dengan kriteria, kemudian diambil kesimpulan. Kesimpulan ini yang kemudian disebut sebagai hasil evaluasi. Menurut Sukmadinata (2006) (dalam Kantun, 2017) penelitian evaluatif dalam konteks pembelajaran merupakan suatu desain atau prosedur dalam mengumpulkan dan menganalisis data secara sistematik untuk menentukan manfaat dari suatu praktik pendidikan. Penelitian studi kasus adalah suatu penelitian yang dilakukan secara intensif, terinci dan mendalam terhadap organisasi, lembaga atau gejala tertentu (Arikunto, 2006). Metode studi kasus digunakan dalam penelitian ini karena penelitian ini akan menggambarkan secara rinci dan mendalam tentang penerapan kawasan dan produk teknologi pendidikan yang telah dilakukan di lembaga pendidikan nonformal.

Penelitian ini dilakukan di LPBB (Lembaga Pelatihan dan Bimbingan Belajar) Solusi Kayumanis dan PKBM (Pusat Kegiatan Belajar Masyarakat) 23 Jakarta sebagai salah satu lembaga pendidikan nonformal yang ada di Jakarta. Durasi penelitian juga relatif pendek yakni selama 5 bulan dari bulan Juni hingga Oktober 2018. Teknik pengumpulan data yang dilakukan dalam penelitian ini adalah: (1) angket; (2) wawancara; dan (3) dokumentasi sebagai data konkret penunjang angket. Teknik pengambilan sampel yang digunakan dalam penelitian ini adalah teknik purposive sampling. Untuk sumber data person, yang menjadi responden adalah tutor di LPBB Solusi Kayumanis dengan jumlah tutor 10 orang. Sedangkan untuk tutor di PKBM Negeri 23 Jakarta jumlah tutor yang menjadi responden 9 orang. Narasumber adalah Kepala PKBM Negeri 23 Jakarta dan Kepala Cabang LPBB Solusi Kayumanis. Untuk sumber data place akan didokumentasikan kondisi lingkungan belajar yang ada di kedua lembaga. Untuk sumber data paper akan didokumentasikan dokumen terkait penerapan kawasan teknologi pendidikan yang ada di ada di kedua lembaga.

Komponen dan indikator yang didapat berdasarkan kawasan dan produk teknologi pendidikan akan menjadi sumber kriteria yang selanjutnya disusun menjadi kisi-kisi instrumen dan dikembangkan menjadi instrumen. Instrumen yang telah disusun oleh peneliti kemudian divalidasi konstruk oleh ahli (expert judgement). Setelah data didapatkan di LPBB Solusi Kayumanis dan PKBM Negeri 23 Jakarta, data kemudian ditabulasi secara kuantitatif menggunakan persentase capaian yang dibandingkan dengan kriteria tertentu seperti yang dikemukakan oleh Sugiyono (2010)

$$
\operatorname{Pr}=\frac{S C}{S I} \times 100 \%
$$

Keterangan:

$\operatorname{Pr}=$ Persentase Capaian

SC = Jumlah Skor Capaian

SI = Jumlah Skor Ideal 
Langkah berikutnya adalah mengkonfirmasi persentase capaian responden dengan kriteria keberhasilan dengan kualifikasi $81-100 \%$ berada pada kategori sangat baik, $61-80 \%$ pada kategori baik, $41-60 \%$ pada kategori cukup baik, $21-40 \%$ pada kategori kurang, dan dibawah $<20 \%$ pada kategori sangat kurang. Selanjutnya data hasil temuan pada angket dikonfirmasi dan dibandingkan dengan data yang didapat dari hasil wawancara dan dokumentasi untuk kemudian secara deskriptif dianalisis dengan perspektif kritis untuk diambil kesimpulan.

\section{HASIL DAN PEMBAHASAN}

\section{Kawasan Penciptaan}

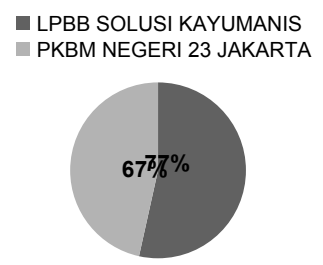

Gambar 1. Persentase Kawasan Penciptaan di Lembaga Pendidikan Nonformal

Berdasarkan pengolahan data lembar angket pada kawasan penciptaan di kedua lembaga, diperoleh hasil persentase $77 \%$ dengan predikat baik untuk LPBB Solusi Kayumanis dan $67 \%$ dengan predikat baik untuk PKBM Negeri 23 Jakarta. Hal tersebut mengindikasikan bahwa kawasan penciptaan telah diterapkan dengan baik di kedua lembaga. Berikut ini akan dijabarkan analisis secara deskriptif:

Dari 10 indikator pada kawasan penciptaan, indikator yang telah diterapkan oleh LPBB Solusi Kayumanis dan PKBM Negeri 23 Jakarta adalah indikator penciptaan media dan sumber belajar, lingkungan belajar, perangkat pembelajaran, analisis karakteristik peserta didik, desain pesan, program pembelajaran, kebijakan dan regulasi. Sedangkan indikator yang belum diterapkan adalah penciptaan metode dan strategi pembelajaran.

LPBB Solusi Kayumanis beserta tutor mengembangkan media dan sumber belajar. Media dan sumber belajar yang dikembangkan oleh LPBB Solusi Kayumanis adalah modul pembelajaran untuk SOKIDS dan SLC (SD-SMP). Modul pembelajaran dikembangkan oleh tim akademik pusat yang bekerja sama dengan tim akademik cabang dan memiliki desain khusus sesuai kebutuhan lembaga. Media dan sumber belajar yang dikembangkan oleh tutor adalah lembaran materi dan gambar peraga. Media dan sumber belajar dikembangkan oleh tutor apabila ada materi pembelajaran yang tidak tersedia di modul pembelajaran dan buku penunjang diluar modul atau saat tutor membutuhkan media dan sumber tambahan untuk menunjang proses belajar.

PKBM Negeri 23 Jakarta tidak mengembangkan media dan sumber belajar sendiri. Karena lembaga belum memiliki tim untuk melakukan pengembangan. PKBM Negeri 23 Jakarta lebih sering menggunakan media dan sumber belajar yang sudah jadi untuk kemudian disesuaikan dengan kebutuhan pembelajaran. Media dan sumber belajar biasanya dikembangkan oleh tutor secara mandiri untuk menunjang proses pembelajaran. Media dan sumber belajar yang dikembangkan oleh tutor adalah lembaran materi, gambar peraga, mainan edukasi (kartu pecahan, kartu gambar), dan objek fisik.

Pengembangan media dan sumber belajar yang dilakukan oleh lembaga LPBB Solusi Kayumanis dan tutor di kedua lembaga telah mencerminkan aktivitas pada kawasan penciptaan, karena pengembangan media dan sumber belajar yang dilakukan mencakup aktivitas analisis kebutuhan, mulai dari pengembangan gagasan hingga menghasilkan produk. Meskipun pengembangan yang dilakukan oleh para tutor cenderung masih sederhana dan terbatas, namun aktivitas yang dilakukan sudah mencakup kawasan penciptaan.

Lingkungan belajar yang dikembangkan oleh LPBB Solusi Kayumanis dan PKBM Negeri 23 Jakarta cenderung pada pengembangan lingkungan belajar sosial. Lingkungan belajar nonsosial yang dikembangkan baru sekadar kondisi pengaturan kelas, pencahayaan, sirkulasi udara, tata letak kursi dan papan tulis. Untuk LPBB Solusi Kayumanis meskipun pengembangan yang dilakukan masih sederhana dan cenderung pada pengembangan lingkungan sosial saja, namun sudah dapat mengakomodasi seluruh proses pembelajaran yang terjadi di lembaga. Namun untuk PKBM Negeri 23 Jakarta karena keterbatasan ruangan yang dimiliki oleh lembaga, belum seluruhnya proses pembelajaran dapat terakomodasi. Proses pembelajaran tata boga, operasi komputer dan mata pelajaran penjaskes belum dapat terakomodasi dengan baik. Tidak terakomodasinya lingkungan belajar dapat mengakibatkan kurang maksimalnya proses pembelajaran yang akan dilaksanakan 
karena kondisi fisik lingkungan belajar termasuk ke dalam hal yang penting di dalam menunjang proses pembelajaran yang akan memfasilitasi proses belajar peserta didik dan membentuk pengetahuan.

LPBB Solusi Kayumanis melakukan pengembangan perangkat pembelajaran yang terdiri dari kalender akademik secara umum, Jadwal Penyampaian Materi (JPM) per semester dan per bulan sebagai bagian dari pelaksanaan kalender akademik, silabus untuk SLC, format Lembar Persiapan Mengajar (LPM) sebagian bagian dari RPP, dan instrumen penilaian hasil belajar. Pengembangan dilakukan oleh tim akademik pusat yang bekerja sama dengan tim akademik cabang. Namun pihak lembaga tidak melakukan pengembangan silabus LPM untuk proses pembelajaran SOKIDS.

Tidak dikembangkannya silabus dan LPM untuk proses pembelajaran SOKIDS akan berdampak pada tidak adanya pedoman dalam melakukan proses pembelajaran untuk tutor. Tutor tidak akan mengetahui kompetensi apa yang harus dicapai oleh peserta didik sehingga tutor pun juga tidak bisa mengembangkan tujuan pembelajaran sendiri. Selain itu tutor hanya berpedoman pada modul pembelajaran yang dibuat oleh lembaga. Sedangkan modul pembelajaran yang dikembangkan oleh lembaga belum secara eksplisit mencantumkan kompetensi yang akan dicapai peserta didik. Modul yang dikembangkan oleh lembaga hanya berisi materi dan praktik yang harus dilakukan peserta didik saja. Hal tersebut akan berdampak pada tutor yang tidak bisa sepenuhnya memfasilitasi belajar peserta didik di dalam proses pembelajaran.

PKBM Negeri 23 belum memiliki tim tersendiri dalam mengembangkan perangkat pembelajaran. Untuk pendidikan kesetaraan lembaga lebih sering menggunakan perangkat pembelajaran yang sudah umum dipakai untuk kemudian disesuaikan dengan kebutuhan lembaga. Pengembangan perangkat pembelajaran biasanya dilakukan oleh tutor pada pendidikan kecakapan hidup. Karena pendidikan kecakapan hidup adalah program khusus yang dimiliki oleh PKBM Negeri 23 Jakarta. Untuk tutor pada pendidikan kesetaraan, biasanya tutor secara mandiri berinisiatif dalam mengembangkan perangkat pembelajaran, seperti mengembangkan tujuan pembelajaran, RPP, dan instrumen penilaian hasil belajar.

Analisis karakteristik peserta didik sudah dilakukan oleh para tutor di LPBB Solusi Kayumanis dan PKBM Negeri 23 Jakarta namun pelaksanaannya masih secara terbatas dan belum memiliki instrumen khusus, baru sekadar pengamatan dan interaksi saja.
Melakukan analisis karakteristik peserta didik sangat penting didalam menyiapkan proses pembelajaran. Karena dengan melakukan analisis karakteristik peserta didik, tutor dan lembaga akan mudah untuk menciptakan dan mengelola pembelajaran, selain itu pihak lembaga dan tutor akan lebih mudah dalam melakukan pengembangan terkait dengan pembelajaran. Apabila analisis peserta didik yang dilakukan masih dalam bentuk sederhana dan belum memiliki instrumen khusus, hal tersebut dapat berdampak pada tidak menyeluruhnya data yang didapat, sehingga intervensi yang akan dilakukan oleh pihak lembaga ataupun pihak tutor tidak akan tepat sasaran.

Desain pesan sudah dilakukan oleh para tutor di kedua lembaga. Untuk tutor di PKBM Negeri 23 Jakarta penerapan desain pesan baru dilakukan secara sederhana dan belum ada regulasi khusus dari lembaga. Sedangkan di LPBB Solusi Kayumanis tutor SLC sudah diwajibkan melakukan desain pesan dan memiliki regulasi khusus namun untuk tutor SOKIDS belum dan tidak diwajibkan oleh lembaga. Tutor SLC 3 hari sebelum melakukan proses pembelajaran, wajib memberikan LPM kepada pihak akademik untuk dikoreksi. Di LPM tersebut tutor diwajibkan untuk melakukan desain pesan dengan melakukan analisis dan menyusun materi berdasarkan tingkatan kognitif. Sedangkan untuk tutor SOKIDS modul sudah diciptakan dan dikembangkan dari level termudah ke level tersulit oleh pihak lembaga. Oleh karena itu tutor tidak diwajibkan untuk melakukan desain pesan sebelum melakukan proses pembelajaran.

Desain pesan dalam tahapan kawasan penciptaan dilakukan setelah analisis kebutuhan yang dalam hal ini masuk dalam analisis karakteristik peserta didik ataupun analisis materi. Desain pesan juga merupakan tahapan yang harus dilalui sebelum menghasilkan produk. Desain pesan memiliki porsi yang cukup besar dalam kawasan penciptaan. Seharusnya desain pesan dapat dilakukan lebih tersistematis dan terstruktur sesuai analisis yang telah dilakukan sebelumnya. Hal ini dilakukan agar produk yang dihasilkan sesuai dengan analisis yang telah dilakukan di awal pengembangan.

Program pembelajaran yang dikembangkan oleh LPBB Solusi Kayumanis adalah program hafalan surat pendek untuk SOKIDS dan program membaca Al-Qur'an untuk jenjang SLC. Sedangkan program pembelajaran yang dikembangkan oleh PKBM negeri 23 Jakarta adalah program kecakapan hidup (life skill) yang mendorong peserta didik untuk menguasai beberapa keterampilan seperti tata boga, 
operasi komputer dan digital printing. Program ini diadakan dengan harapan peserta didik setelah lulus dapat memiliki keterampilan yang dapat berguna di masyarakat. Hasil penelitian tersebut mempertegas hasil penelitian sebelumnya. Penelitian serupa mengenai program pembelajaran yang dikembangkan oleh lembaga pendidikan nonformal sesuai dengan karakteristik dan tujuan dari lembaga. Program pembelajaran yang dikembangkan biasanya berupa program kecakapan hidup yang menumbuhkan keterampilan peserta didik.

Metode dan strategi pembelajaran belum dikembangkan oleh kedua lembaga LPBB Solusi Kayumanis dan PKBM Negeri 23 Jakarta. Tutor hanya menggunakan metode dan strategi pembelajaran yang sudah umum dan dikondisikan dengan kebutuhan pembelajaran. Metode yang biasa digunakan oleh tutor di kedua lembaga diantaranya metode ceramah, drilling soal, diskusi. Strategi yang baisa digunakan adalah strategi pembelajaran kontekstual, kooperatif, ekspositori.

LPBB Solusi Kayumanis mendorong staf dan tutor untuk terus mengembangkan inovasi terkait pembelajaran meski pengembangan tersebut tidak terlalu sering, karena lembaga terkadang masih menggunakan produk jadi yang dimodifikasi. Untuk PKBM Negeri 23 Jakarta, lembaga menyerahkan sepenuhnya kepada tutor untuk mengembangkan berbagai hal terkait dengan pembelajaran namun tetap berkoordinasi dengan lembaga. Tapi pihak lembaga belum secara eksplisit mendorong tutor untuk mengembangkan berbagai hal terkait dengan pembelajaran karena kondisi lembaga yang masih terbatas.

\section{Kawasan Penggunaan}

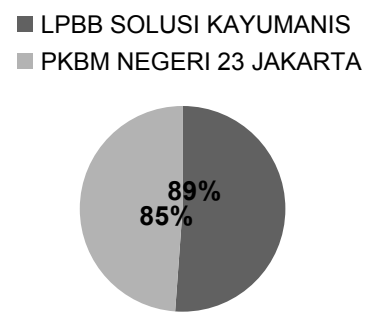

Gambar 2. Persentase Kawasan Penggunaan di Lembaga Pendidikan Nonformal

Berdasarkan pengolahan data lembar angket pada kawasan penggunaan di kedua lembaga, diperoleh hasil persentase $89 \%$ dengan predikat sangat baik untuk LPBB Solusi Kayumanis dan $85 \%$ dengan predikat sangat baik untuk PKBM Negeri 23 Jakarta. Hal tersebut mengindikasikan bahwa kawasan penggunaan telah diterapkan dengan sangat baik di kedua lembaga. Berikut ini akan dijabarkan analisis secara deskriptif:

Dari 8 indikator pada kawasan penggunaan, seluruh indikator telah diterapkan oleh LPBB Solusi Kayumanis dan PKBM Negeri 23 Jakarta. Indikator tersebut adalah indikator penggunaan media dan sumber belajar, lingkungan belajar, perangkat pembelajaran, metode dan strategi pembelajaran, program pembelajaran, kebijakan dan regulasi. LPBB Solusi Kayumanis menggunakan media dan sumber belajar yang sudah jadi dan ada di pasaran untuk kemudian disesuaikan dengan kebutuhan lembaga. Media dan sumber belajar yang digunakan oleh lembaga adalah mainan edukasi seperti puzzle dan flash card, buku penunjang di luar modul, dan gambar peraga. Sedangkan tutor menggunakan media dan sumber belajar yang dikembangkan oleh lembaga, yakni modul pembelajaran.

Sama halnya seperti LPBB Solusi Kayumanis, PKBM negeri 23 Jakarta juga menggunakan media dan sumber belajar yang sudah jadi dan ada di pasaran untuk kemudian disesuaikan dengan kebutuhan lembaga. Media dan sumber belajar yang digunakan oleh lembaga dan tutor adalah buku pembelajaran tematik untuk jenjang paket $A$, buku pembelajaran sesuai mata pelajaran untuk jenjang paket $B$ dan $C$, peta, buku pengayaan, papan tulis, proyektor LCD, peta, dan monitor komputer. Memilah dan memilih media dan sumber belajar yang tepat sesuai dengan kebutuhan pembelajaran dan menggunakannya secara tepat termasuk dalam cakupan aktivitas pada kawasan penggunaan. Penggunaan media dan sumber belajar yang tepat tersebut akan membuat proses belajar peserta didik menjadi lebih maksimal karena pesan yang akan disampaikan, dalam hal ini materi pembelajaran, akan dapat tersampaikan dengan baik.

Tutor di LPBB Solusi Kayumanis menggunakan lingkungan belajar yang disediakan oleh lembaga. Secara sosial, tutor mengkondisikan lingkungan belajar agar tertib dan kondusif. Sedangkan secara nonsosial, tutor mengkondisikan letak kursi peserta didik sesuai dengan metode yang sedang digunakan dalam pembelajaran. Selain tutor, LPBB Solusi Kayumanis juga menggunakan lingkungan belajar di luar lingkup lembaga. Lembaga biasanya melakukan outing class untuk peserta didik. Lingkungan di luar cakupan lembaga yang biasanya digunakan lembaga untuk memfasilitasi proses pembelajaran adalah 
taman bermain, peternakan, supermarket. Tujuan penggunaan lingkungan belajar di luar cakupan lembaga adalah agar peserta didik dapat berinteraksi langsung dengan lingkungan luar sehingga dapat memperkaya proses belajar peserta didik.

Tutor di PKBM Negeri 23 Jakarta juga menggunakan lingkungan belajar yang telah disediakan oleh lembaga. Apabila peserta didik dalam jumlah yang sedikit, tutor biasanya mengkondisikan lingkungan belajar secara sosial agar tertib dan kondusif. Secara nonsosial, tutor biasanya mengkondisikan kelas dengan mengatur letak kursi atau mengatur kelas sesuai dengan simulasi atau praktik yang akan dilakukan. Namun apabila jumlah peserta didik cukup banyak seperti di program paket B dan C, maka tutor biasanya hanya mengkondisikan lingkungan belajar secara sosial saja. Namun sebenarnya jumlah yang tidak proporsional antara jumlah tutor dengan jumlah peserta didik dapat mengakibatkan tidak maksimalnya proses pembelajaran. Sehingga persentase ketercapaian kompetensi bisa tidak maksimal.

Dengan keterbatasan ruangan yang dimiliki pihak lembaga, pihak lembaga sudah mengatur dan mensiasati sedemikian rupa agar lingkungan belajar yang ada dapat dipergunakan dan dapat memfasilitasi proses pembelajaran, meskipun belum semuanya terakomodasi karena keterbatasan ruangan. Pembelajaran yang belum dapat terakomodasi adalah pembelajaran untuk tata boga, operasi komputer dan penjaskes.

LPBB Solusi Kayumanis tidak menggunakan perangkat pembelajaran yang sudah jadi, karena lembaga mengembangkan sendiri. Sedangkan tutor menggunakan perangkat pembelajaran yang telah dikembangkan oleh lembaga, yang terdiri dari kalender akademik, silabus dan instrumen penilaian hasil belajar. Lembaga mengembangkan perangkat pembelajaran yang telah disesuaikan dengan kebutuhan harian, bulan dan per semester. Tutor hanya tinggal memilih dan menggunakan perangkat pembelajaran yang telah dikembangkan oleh lembaga di dalam proses pembelajaran.

PKBM Negeri 23 Jakarta beserta tutor memilih dan menggunakan perangkat pembelajaran yang umum dipakai dalam proses pembelajaran. Kalender akademik mengacu dan menggunakan kalender akademik yang dikeluarkan oleh Dinas Pendidikan Pemprov DKI Jakarta. Silabus dan RPP mengacu dan menggunakan silabus dan RPP yang berasal dari Kemendikbud. Sedangkan instrumen penilaian hasil belajar menggunakan instrumen tes yang biasanya terdapat di buku-buku pembelajaran ataupun yang dapat diakses melalui internet.

Tutor di kedua lembaga LPBB Solusi Kayumanis dan PKBM Negeri 23 Jakarta menggunakan metode dan strategi pembelajaran yang umum dipakai dalam proses pembelajaran dan disesuaikan dengan kebutuhan. Metode yang biasa digunakan oleh tutor di LPBB Solusi Kayumanis adalah metode ceramah, drilling soal, diskusi. Strategi yang digunakan adalah strategi pembelajaran kontekstual dan kooperatif. Sedangkan metode yang digunakan oleh tutor di PKBM Negeri 23 Jakarta adalah metode ceramah, tanya jawab, diskusi, peragaan. Dan strategi yang digunakan adalah strategi kooperatif, ekspositori dan inquiry. Penggunaan metode dan strategi pembelajaran tertentu memperkuat hasil penelitian dari Teguh Hari (2015) dan Rosfita (2017) tentang penggunaan metode tertentu dalam proses pembelajaran di lembaga pendidikan nonformal. Metode - metode tersebut membuat proses pebelajaran menjadi lebih interaktif dan membuat siswa lebih mudah memahami materi.

Kedua lembaga yakni LPBB Solusi Kayumanis dan PKBM Negeri 23 Jakarta selain mengembangkan program tersendiri namun juga memilih program pembelajaran yang umum ada di luar untuk kemudian digunakan oleh lembaga. Program pembelajaran yang digunakan oleh LPBB Solusi kayumanis adalah program pembelajaran basic English untuk SOKIDS, dan program pembelajaran kurikulum KTSP dan 2013 untuk SLC. Sama halnya seperti LPBB Solusi Kayumanis, PKBM Negeri 23 Jakarta juga menggunakan program pembelajaran kurikulum KTSP dan 2013 untuk proses pembelajaran pada pendidikan kesetaraan.

LPBB Solusi Kayumanis dan PKBM Negeri 23 Jakarta sama-sama memiliki kebijakan dan regulasi untuk memilih, menyediakan dan menggunakan produk-produk terbaru terkait dengan pembelajaran secara kontinu. Meskipun PKBM Negeri 23 Jakarta belum bisa terlalu sering untuk melakukan hal tersebut karena kondisi lembaga yang masih cukup terbatas. 


\section{Kawasan Pengelolaan}

- LPBB SOLUSI KAYUMANIS

PKBM NEGERI 23 JAKARTA

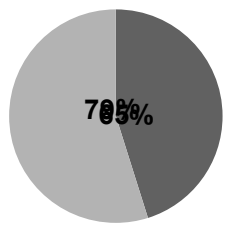

Gambar 3. Persentase Kawasan Pengelolaan di Lembaga Pendidikan Nonformal

Berdasarkan pengolahan data lembar angket pada kawasan pengelolaan di kedua lembaga, diperoleh hasil persentase $65 \%$ dengan predikat baik untuk LPBB Solusi Kayumanis dan 79\% dengan predikat baik untuk PKBM Negeri 23 Jakarta. $\mathrm{Hal}$ tersebut mengindikasikan bahwa kawasan pengelolaan telah diterapkan dengan baik di kedua lembaga. Berikut ini akan dijabarkan analisis secara deskriptif:

Dari 5 indikator pada kawasan pengelolaan, seluruh indikator telah diterapkan oleh LPBB Solusi Kayumanis dan PKBM Negeri 23 Jakarta. Indikator yang telah diterapkan adalah indikator pengelolaan media dan sumber belajar, lingkungan belajar, perangkat pembelajaran, dan pengelolaan personel. Berdasarkan data yang dihimpun melalui kuesioner, lembar wawancara dan dokumentasi, LPBB Solusi Kayumanis melakukan pengelolaan terhadap media dan sumber belajar. Pengelolaan media dan sumber belajar yakni secara fisik dan secara daring. Secara fisik, lembaga menyediakan rak buku sebagai tempat untuk meletakkan media dan sumber belajar yang ada, seperti modul, buku penunjang, gambar peraga, mainan edukasi dan mengontrol kondisinya setiap awal atau akhir semester. Pihak lembaga juga mengecek kondisi papan tulis setiap beberapa bulan sekali. Secara daring, lembaga menyimpan modul pembelajaran yang dikembangkan oleh lembaga dalam bentuk softcopy yang disimpan di aplikasi Dropbox. Namun lembaga belum melakukan inventarisasi terhadap media dan sumber belajar yang dimiliki, sehingga beberapa kali media dan sumber belajar yang ada secara fisik hilang dan tidak diketahui oleh lembaga.

Media dan sumber belajar berfungsi untuk memfasilitasi pembelajaran (facilitating learning) untuk memberi pengalaman belajar otentik bagi peserta didik. Dengan tidak dikelolanya media dan sumber belajar dengan baik sehingga menyebabkan kehilangan, hal tersebut akan berdampak pada terhambatnya proses pembelajaran. Sehingga proses pembelajaran yang seharusnya dapat terfasilitasi dengan media dan sumber belajar untuk memberikan pengalaman belajar otentik bagi peserta didik menjadi tidak dapat terlaksana dengan baik, dan kinerja peserta didik di dalam proses pembelajaran pun menjadi tidak maksimal.

PKBM Negeri 23 Jakarta juga melakukan pengelolaan terhadap media dan sumber belajar yang dimiliki oleh lembaga. Pengelolaan yang dilakukan oleh lembaga adalah secara fisik, yakni dengan menyediakan lemari khusus sebagai tempat meletakkan media dan sumber belajar yang ada. Selain itu lembaga melakukan inventarisasi terhadap media dan sumber belajar yang dimiliki sehingga jumlah media pembelajaran yang ada tercatat dengan baik dan meminimalisir kehilangan.

LPBB Solusi Kayumanis menyediakan sistem untuk mengelola lingkungan belajar agar kondisinya tetap baik dan dapat kontinu digunakan. Pengelolaan yang dilakukan oleh LPBB Solusi Kayumanis diantaranya dalam beberapa bulan sekali lembaga akan melakukan kontrol terhadap kondisi kelas, dari mulai pencahayaan, sirkulasi udara melalui AC, kondisi meja dan kursi. Selain itu, lembaga melalui staf akademik juga melakukan pengontrolan terhadap kondisi lingkungan sosial agar tetap kondusif dalam proses pembelajaran.

Sama halnya seperti LPBB Solusi Kayumanis, PKBM Negeri 23 Jakarta juga melakukan pengelolaan pada lingkungan belajar. Secara fisik lembaga mengelola agar lingkungan belajar tetap bersih, dan nyaman, yakni dengan memperhatikan dan mengkondisikan penataan kelas, dari mulai kursi peserta didik satu sama lain, kursi guru, dan letak papan tulis. Namun dalam pengelolaan lingkungan belajar fisik tutor memiliki keterbatasan dalam mengatur letak kursi apabila peserta didik dalam jumlah yang banyak. Sedangkan untuk lingkungan belajar sosial, lembaga bersinergi dengan tutor untuk mengelola. Pihak lembaga dan tutor memiliki peraturan tertentu untuk peserta didik agar lingkungan belajar tetap kondusif dan tertib.

Pengelola perangkat pembelajaran di LPBB Solusi Kayumanis adalah staf akademik yang bersinergi dengan kepala cabang. Kalender akademik, silabus dan instrumen penilaian hasil belajar dikelola dalam bentuk softcopy yang disimpan di aplikasi Dropbox. Untuk Lembar Persiapan Mengajar (LPM) yang dalam hal ini adalah RPP, dikelola oleh lembaga dalam bentuk hardcopy yang dijilid persemester. Selain lembaga, tutor juga melakukan pengelolaan terhadap instrumen penilaian hasil belajar yang dikembangkan 
sendiri oleh para tutor.

PKBM Negeri 23 Jakarta juga sudah melakukan pengelolaan pada perangkat pembelajaran. Kalender akademik sudah diarsipkan setiap tahun ajaran. Selain itu tutor juga ikut melakukan pengelolaan bersama dengan lembaga dengan mengarsipkan silabus, RPP dan instrumen penilaian hasil belajar. Namun untuk silabus, RPP dan instrumen penilaian hasil belajar lembaga tidak seluruhnya mengarsipkan dokumen tersebut. Lembaga hanya mengarsipkan beberapa mata pelajaran saja sebagai contoh arsip. Para tutor secara mandiri melakukan pengarsipan penuh terhadap silabus, RPP dan instrumen penilaian hasil belajar yang mereka miliki.

Pengarsipan, pengontrolan dalam kurun waktu tertentu terhadap produk-produk teknologi pendidikan seperti media dan sumber belajar, lingkungan belajar dan perangkat pembelajaran adalah bentuk penerapan kawasan pengelolaan. Pengelolaan produk-produk teknologi pendidikan tersebut lebih ditekankan pada dimensi mengelola produk yang sudah ada/jadi. Dimana produk-produk teknologi pendidikan tersebut dikelola berdasarkan pada teori dan metodologi manajemen tertentu.

Pengelolaan personel dalam bidang teknologi pendidikan pada dasarnya banyak menggunakan pengembangan sumber daya manusia dan juga teknologi kinerja manusia, dimana pengelolaan personel diarahkan untuk menempatkan personel yang tepat untuk aktivitas tertentu, termasuk proyek peningkatan kualitas personel melalui serangkaian pelatihan/training. Aktivitas pengelolaan personel berfokus untuk meningkatkan kinerja dengan menggunakan bantuan atau intervensi teknologi.

Pengelolaan personel sudah dilakukan oleh LPBB Solusi Kayumanis untuk meningkatkan kualitas tutor. Untuk tutor SLC (SD-SMP), lembaga melakukan pelatihan 3 sampai 6 bulan sekali. Sebelum melakukan pelatihan untuk tutor SLC (SD-SMP) lembaga biasanya melakukan pemetaan kisi-kisi sebelum membuat instrumen tes, dimana pemetaan tersebut akan dijadikan dasar acuan kompetensi yang harus dikuasai tutor ketika proses pelatihan. Namun untuk tutor SOKIDS, lembaga tidak melakukan jadwal khusus, lembaga biasanya hanya melakukan minimal 1 kali pelatihan dalam kurun waktu 1 tahun. Dan lembaga tidak melakukan pemetaan kompetensi sebelum melakukan pelatihan. Lembaga biasanya meminta masukan kepada tutor, kompetensi apa saja yang mereka butuhkan, untuk kemudian lembaga melakukan pelatihan berdasarkan kompetensi yang diminta dan dibutuhkan oleh tutor SOKIDS. Secara keseluruhan tutor sudah memiliki kesadaran pribadi untuk secara berkala meningkatkan kualitas dirinya dengan mengikuti pelatihan secara mandiri di luar sistem yang ada pada lembaga.

Pemetaan kompetensi sebelum melakukan pelatihan sangat penting karena berkaitan dengan analisis kebutuhan pelatihan. Analisis kebutuhan pelatihan diperlukan untuk mengidentifikasi kebutuhan belajar atau kompetensi yang akan dicapai. Apabila analisis yang dilakukan menyeluruh, maka dengan intervensi teknologi yang tepat dan terintegrasi kinerja personel dapat meningkat setelah dilakukan pelatihan. Namun apabila melakukan pelatihan tanpa analisis kebutuhan maka intervensi yang akan diberikan saat pelatihan tidak akan tepat sasaran untuk meningkatkan kinerja.

Berbeda halnya dengan LPBB Solusi Kayumanis, PKBM Negeri 23 Jakarta belum melakukan pengelolaan personel secara mandiri. Namun PKBM Negeri 23 Jakarta bekerjasama dengan P3PNFI (Pusat Pelatihan dan Pengembangan Pendidikan Nonformal dan Informal) dan P3PAUDNI (Pusat Pelatihan dan Pengembangan Pendidikan Anak Usia Dini, Nonformal dan Informal) Wilayah Kota Jakarta atau sekarang yang berganti nama menjadi P3PAUD dan DIKMAS (Pusat Pelatihan dan Pengembangan Pendidikan Anak Usia Dini, dan Pendidikan Masyarakat). Lembaga secara berkala mengirimkan tutor untuk mengikuti pelatihan terkait dengan peningkatan kompetensi tutor di dalam melakukan pembelajaran.

Sebelum mengirimkan tutor untuk mengikuti pelatihan, lembaga biasanya mempertimbangkan 3 hal. Pertama tutor yang bukan sebagai lulusan sarjana pendidikan, lembaga mengirim mereka untuk lebih meningkatkan kompetensi mereka sebagai tutor, kedua tutor yang sesuai dengan mata pelajaran dan program yang diminta oleh P3PNFI dan P3PAUDNI, dan ketiga adalah tutor yang jarang mengikuti pelatihan. Mayoritas tutor pun sudah memiliki kesadaran pribadi untuk berkala meningkatkan kualitas dirinya dengan mengikuti pelatihan secara mandiri di luar sistem yang ada pada lembaga. Meskipun masih ada sedikit tutor yang belum memiliki kesadaran pribadi untuk itu. 


\section{Kawasan Evaluasi}
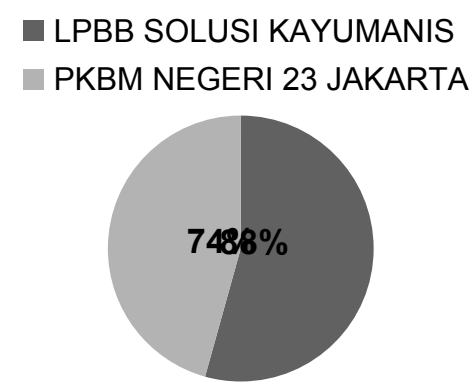

Gambar 4. Persentase Kawasan Evaluasi di Lembaga Pendidikan Nonformal

Berdasarkan pengolahan data lembar angket pada kawasan evaluasi di kedua lembaga, diperoleh hasil persentase $88 \%$ dengan predikat baik untuk LPBB Solusi Kayumanis dan $74 \%$ dengan predikat baik untuk PKBM Negeri 23 Jakarta. Hal tersebut mengindikasikan bahwa kawasan evaluasi telah diterapkan dengan baik di kedua lembaga. Berikut ini akan dijabarkan analisis secara deskriptif:

Dari 12 indikator pada kawasan evaluasi, seluruh indikator telah diterapkan oleh LPBB Solusi Kayumanis dan PKBM Negeri 23 Jakarta. Indikator yang telah diterapkan adalah indikator model pengembangan produk, evaluasi media dan sumber belajar, evaluasi lingkungan belajar, evaluasi perangkat pembelajaran, evaluasi personel, evaluasi metode dan strategi pembelajaran, pengukuran acuan patokan, penilaian formatif dan sumatif, analisis pembelajaran, dan evaluasi program.

Model pembelajaran yang digunakan oleh LPBB Solusi Kayumanis dalam mengembangkan produk pembelajaran menggunakan paradigma ADDIE (Analysis, Design, Development, Implementation and Evaluation), baik yang dilakukan oleh lembaga ataupun tutor. Lembaga dan para tutor ketika mengembangkan produk pembelajaran hal yang dilakukan pertama kali adalah melihat kebutuhan di lembaga atau proses pembelajaran, lalu berikutnya berdasarkan kebutuhan membuat produk tersebut, setelah produk jadi, produk kemudian diterapkan di lembaga atau dalam proses pembelajaran, dievaluasi, dan terakhir bila ada yang perlu diperbaiki akan direvisi. Namun yang membedakan, pengembangan yang dilakukan oleh pihak lembaga dengan yang dilakukan oleh tutor adalah evaluasi yang dilakukan. Evaluasi yang dilakukan oleh lembaga dilakukan oleh bagian akademik, dilakukan secara menyeluruh, terstruktur (menggunakan instrumen khusus), dan berkala. Namun evaluasi yang dilakukan oleh tutor masih dalam bentuk sederhana, dan belum terstruktur.
Sama halnya seperti yang dilakukan oleh LPBB Solusi Kayumanis, PKBM Negeri 23 Jakarta juga menggunakan paradigma ADDIE dalam mengembangkan suatu produk. Namun yang menggunakan paradigma tersebut hanya para tutor karena lembaga tidak melakukan pengembangan. Tutor biasanya melihat kebutuhan dalam proses pembelajaran misalnya media pembelajaran atau instrumen penilaian hasil belajar, lalu berikutnya tutor membuat produk tersebut, dan diterapkan ke peserta didik sesuai dengan kebutuhan dan dievaluasi bila ada kekurangan. Sama halnya yang dilakukan oleh para tutor di LPBB Solusi Kayumanis, evaluasi yang dilakukan oleh tutor di PKBM Negeri 23 masih dalam bentuk sederhana karena tidak memiliki instrumen khusus untuk melakukan evaluasi.

Media dan sumber belajar yang digunakan oleh LPBB Solusi Kayumanis di luar modul pembelajaran yang dikembangkan, lembaga biasanya mengevaluasi setiap bulan secara lisan dalam upgrading bulanan staf dan tutor. Selain media dan sumber belajar, evaluasi juga dilakukan terhadap lingkungan belajar, metode dan strategi pembelajaran. Evaluasi yang dilakukan lembaga masih dalam bentuk sederhana dan belum memiliki instrumen khsusus. Evaluasi yang dilakukan baru sebatas pengamatan, pencatatan dan evaluasi secara lisan.

Staf akademik LPBB Solusi Kayumanis setiap hari mengontrol pembelajaran di lembaga, dalam hal ini mengontrol penggunaan media dan sumber belajar, lingkungan belajar, mettode dan strategi pembelajaran yang digunakan tutor. Dari aktivitas kontrol tersebut biasanya dibuatkan catatan khusus oleh staf akademik. Akumulasi dari aktivitas kontrol tersebut akan dievaluasi secara lisan oleh kepala cabang dan bagian akademik setiap bulan saat upgrading bulanan staf dan tutor. Selain itu, secara mandiri tutor juga melakukan evaluasi terhadap media dan sumber belajar yang digunakan, lingkungan belajar, serta metode dan strategi yang digunakan.

Sama seperti yang dilakukan oleh LPBB Solusi Kayumanis, evaluasi yang dilakukan oleh PKBM Negeri 23 Jakarta untuk media dan sumber belajar, lingkungan belajar serta metode dan strategi pembelajaran masih dilakukan dalam bentuk sederhana dan belum memiliki instrumen khusus. Tapi berbeda dengan evaluasi yang dilakukan oleh LPBB Solusi Kayumanis, PKBM Negeri 23 Jakarta hanya melakukan evaluasi setiap satu tahun sekali saat monitoring dan evaluasi yang teragendakan di dalam rapat antara tutor dan penyelenggara PKBM. Lembaga biasanya mengevaluasi media dan sumber belajar untuk melihat 
kondisi dan ketersediaan jumlah. Untuk lingkungan belajar sosial, lembaga bersama tutor mengevaluasi keefektifan peraturan yang dibuat oleh lembaga dan tutor untuk peserta didik. Untuk lingkungan belajar fisik akan dievaluasi apabila terjadi kerusakan. Sedangkan metode dan strategi pembelajaran akan dilakukan evaluasi mengenai keefektifan metode dan strategi yang digunakan. Namun mayoritas tutor masih belum memiliki kesadaran dalam mengeveluasi secara mandiri media dan sumber belajar yang digunakan, lingkungan belajar, serta metode dan strategi yang digunakan.

Analisis pembelajaran yang dilakukan oleh tutor LPBB Solusi Kayumanis dilakukan setelah proess pembelajaran selesai. Di akhir proses pembelajaran tutor biasanya menganalisis hal-hal yang menjadi kekurangan atau kelebihan pada pembelajaran yang sudah terjadi. Kemudian dicatatkan di bank data siswa untuk diketahui oleh bagian akademik dan kepala cabang, sebagai bagian dari masukan dan evaluasi dari tutor terhadap proses pembelajaran yang sudah dilakukan.

PKBM Negeri 23 Jakarta tidak secara spesifik menginstruksikan tutor untuk melakukan analisis pembelajaran, namun biasanya tutor dengan kesadaran pribadi melakukan analisis di akhir pembelajaran untuk mempermudah proses pembelajaran. Hal ini dikarenakan peserta didik pada program kesetaraan rata-rata adalah peserta didik yang putus sekolah. Jadi tutor perlu melakukan analisis di akhir proses pembelajaran agar proses pembelajaran selanjutnya dapat mudah dimengerti oleh peserta didik. Analisis yang dilakukan tutor di kedua lembaga pun masih sederhana dan terbatas, belum memiliki instrumen khusus.

LPBB Solusi Kayumanis sudah melakukan evaluasi terhadap perangkat pembelajaran. Untuk kalender akademik dan silabus SLC (SD-SMP) dievaluasi oleh lembaga setiap 1 bulan sekali. Lembaga rutin untuk memeriksa kekurangan yang ada pada kalender akademik dan silabus. Evaluasi dan pemeriksaan tersebut dilakukan oleh kepala cabang dan staf akademik. Namun seperti yang telah dijelaskan sebelumnya. Sedangkan untuk silabus SOKIDS lembaga tidak melakukan evaluasi karena tingkat SOKIDS tidak memiliki silabus tertentu seperti halnya tingkat SLC

Lembar Persiapan Mengajar (LPM) atau nama lain RPP yang dimiliki oleh LPBB Solusi Kayumanis untuk tutor SLC (SD-SMP) dievaluasi oleh staf akademik setiap 3 hari sebelum proses pembelajaran dilakukan. Setiap tutor wajib menyerahkan LPM tersebut kepada staf akademik untuk diketahui kelayakannya. Lembar Persiapan Mengajar (LPM) yang sudah dievaluasi oleh staf akademik akan ditandatangani dan diberikan catatan khusus mengenai hal-hal yang kurang dari LPM tersebut. Selain LPM, tutor juga wajib menyerahkan instrumen penilaian hasil belajar kepada staf akademik untuk dievaluasi apabila tutor menggunakan instrumen lain di luar instrumen penilaian hasil belajar yang sudah ada di dalam modul pembelajaran.

PKBM Negeri 23 Jakarta juga sudah melakukan evaluasi terhadap perangkat pembelajaran seperti LPBB Solusi Kayumanis namun PKBM Negeri 23 Jakarta hanya melakukan evaluasi setiap satu tahun sekali saat rapat antara tutor dan penyelenggara PKBM. Lembaga biasanya mengevaluasi keefektifan dari kalender akademik, kesesuaian materi, waktu dan kompetensi yang akan dicapai dari silabus dan RPP yang digunakan oleh tutor dan keefektifan berbagai instrumen penilaian hasil belajar yang sudah digunakan dalam proses pembelajaran. Evaluasi yang dilakukan juga masih dalam bentuk yang sederhana dan terbatas, karena belum memiliki instrumen khusus.

LPBB Solusi Kayumanis melakukan evaluasi terhadap program pembelajaran yang dimiliki oleh lembaga setiap sebulan sekali saat upgrading bulanan staf dan tutor. Evaluasi yang dilakukan masih secara lisan dan belum memiliki instrumen khusus. Saat upgrading bulanan tersebut, staf akademik biasanya sudah membawa catatan mengenai hal-hal apa saja yang perlu dievaluasi sebulan terakhir terkait penerapan program pembelajaran yang dimiliki oleh lembaga. Lalu kepala cabang, tutor dan staf akan mengevaluasi kekurangan yang ada dan mencari solusi bersama-sama dari kekurangan tersebut. Sama halnya seperti LPBB Solusi Kayumanis, PKBM Negeri 23 Jakarta juga sudah melakukan evaluasi terhadap program pembelajaran yang dimiliki oleh lembaga. Hanya saja evaluasi yang dilakukan lembaga hanya satu tahun sekali.

Dalam Hanum (2015) evaluasi adalah sebuah kegiatan yang sistematis untuk mengumpulkan informasi yang bermanfaat tentang proses kerja suatu hal, yang kemudian informasi tersebut dapat digunakan untuk menentukan alternatif yang tepat dalam pengambilan keputusan dan menilai ketercapaian dari proses tersebut. Oleh karena itu, bila evaluasi yang dilakukan masih dalam bentuk sederhana, dan terbatas, maka informasi yang akan terkumpul menjadi tidak maksimal selain itu penilaian yang dilakukan bisa menjadi tidak objektif. Sehingga pengambilan keputusan akan objek yang dievaluasi bisa menjadi 
tidak tepat.

Sebelum melakukan proses evaluasi terhadap suatu objek maka langkah penting dan krusial adalah merumuskan masalah evaluasi dan menentukan tujuan evaluasi. Hal tersebut penting dilakukan agar lembaga dapat menganalisis masalah yang ada untuk kemudian dapat ditentukan jenis evaluasi yang akan dilakukan. Lembaga akan melakukan jenis evaluasi formatif yang dilakukan secara kontinu dan berkelanjutan untuk proses perubahan yang lebih besar atau evaluasi sumatif yang dilakukan untuk menilaian keseluruhan objek evaluasi berdasarkan tujuan atau standar tertentu.

LPBB Solusi Kayumanis melakukan evaluasi terkait kinerja tutor SLC (SD-SMP) 3-6 bulan sekali melalui tes kompetensi akademik yang berisi pengujian pengetahuan mengenai materi pembelajaran dan tes yang berisi pengujian kemampuan dalam penguasaan kelas. Namun untuk tutor SOKIDS lembaga belum melakukan tes seperti yang dilakukan untuk tutor SLC (SD-SMP). Lembaga hanya melakukan monitoring dan pengamatan langsung kepada tutor SOKIDS sebagai bentuk evaluasi. Sedangkan untuk kegiatan harian, biasanya dalam kurun waktu tertentu bagian akademik akan melakukan observasi terhadap kinerja tutor ketika melakukan proses pembelajaran di kelas. Sama halnya seperti LPBB Solusi Kayumanis, PKBM Negeri 23 Jakarta juga melakukan evaluasi terkait kinerja tutor di lembaga. Lembaga memiliki instrumen khusus untuk mengevaluasi kinerja tutor. Dan proses evaluasi tersebut dilakukan dalam kurun waktu 1 tahun sekali.

Evaluasi kinerja adalah hal yang sangat penting sebagai penilaian hasil kerja nyata dengan standar kualitas maupun kuantitas yang dihasilkan oleh setiap personel di sebuah organisasi. Evaluasi kinerja terhadap personel mutlak harus dilakukan untuk mengetahui prestasi yang dapat dicapai. Penilaian prestasi penting bagi setiap personel yang ada di dalam organisasi dan berguna bagi organisasi untuk mengambil keputusan dan menetapkan tindakan selanjutnya. Instrumen evaluasi kinerja yang valid dan reliabel penting untuk mengukur seberapa tepat personel yang ada di organisasi menjalankan fungsi yang sesuai. Bila evaluasi yang dilakukan tidak tepat, karena evaluasi yang dilakukan belum memiliki instrumen khusus, maka akan sulit untuk menentukan analisis kebutuhan yang kemudian akan berdampak pada tidak tepatnya intervensi atau pelatihan yang akan diberikan.

Tutor SLC (SD-SMP) di LPBB Solusi Kayumanis menetapkan Kriteria Ketuntasan Minimal (KKM) sebagai bentuk penilaian acuan patokan dalam proses pembelajaran. Tutor lebih sering menggunakan Patokan Acuan Norma (PAN) untuk menetapkan KKM bagi peserta didik. Sedangkan untuk tutor SOKIDS KKM yang ditetapkan oleh tutor bukan berupa angka. Tapi berupa deskripsi mengenai pencapaian siswa selama proses pembelajaran, seperti pemahaman siswa mengenal huruf dan angka, perkembangan motorik halus dan kasar siswa serta kerapihan membentuk garis dan menulis.

PKBM Negeri 23 Jakarta juga menerapkan Minimal (KKM) untuk melihat ketercapaian kompetensi sebagai bagian dari bentuk penilaian acuan patokan. Tutor di PKBM Negeri 23 Jakarta juga cenderung menggunakan Patokan Acuan Norma (PAN) untuk menetapkan KKM karena kondisi kognitif peserta didik yang tidak bisa disamakan dengan peserta didik pada pendidikan formal.

Penilaian acuan norma (PAN) (dalam Reza, 2015) adalah penilaian yang diacukan kepada rata-rata kelompoknya. Dengan demikian dapat diketahui posisi kemampuan peserta didik di dalam kelompoknya. Untuk itu norma atau kriteria yang digunakan dalam penilaian ini adalah menentukan derajat penguasaan seorang peserta didik yang dibandingkan dengan nilai rata-rata kelasnya. Dengan kata lain, prestasi yang dicapai seseorang posisinya sangat bergantung pada prestasi kelompoknya. Keuntungan sistem ini adalah dapat diketahui prestasi kelompok atau kelas sehingga sekaligus dapat diketahui keberhasilan pengajaran bagi semua peserta didik. Kelemahan dari penilaian ini adalah kurangnya meningkatkan kualitas hasil belajar selain itu kurang praktis bila peserta didik dalam jumlah yang cukup banyak. Sistem ini juga dapat dikatakan kurang untuk menggambarkan tercapainya tujuan pembelajaran, karena keberhasilan pembelajaran ditentukan oleh kemampuan peserta didik dalam kelompoknya bukan dengan tujuan yang seharusnya dicapai.

LPBB Solusi Kayumanis melakukan penilaian formatif dan sumatif dalam proses pebelajaran. Lembaga memiliki prosedur kegiatan pembelajaran yang menjadi panduan tutor di dalam melakukan proses pembelajaran. Dalam prosedur kegiatan pembelajaran tersebut terlihat bahwa setiap melakukan proses pembelajaran tutor diwajibkan melakukan penilaian harian terhadap peserta didik SOKIDS dan SLC (SD-SMP) sebagai bagian dari penilaian formatif. Selain penilaian harian, penilaian formatif yang dilakukan lembaga adalah ujian tryout untuk Penilaian Tengah Semester (PTS). Selain penilaian formatif lembaga juga menerapkan penilaian sumatif. Untuk penilaian sumatif, lembaga mewajibkan peserta 
didik mengikuti penilaian sumatif yang disediakan oleh lembaga. Untuk peserta didik SLC (SD-SMP) lembaga menjadwalkan tryout untuk Penilaian Akhir Semester (PAS), sedangkan untuk peserta didik SOKIDS lembaga melakukan ujian akhir sebelum peserta didik dinyatakan lulus dan siap memasuki jenjang sekolah dasar (SD).

PKBM Negeri 23 Jakarta juga melakukan penilaian harian sebagai bentuk penilaian formatif. Penilaian harian yang dilakukan lebih bervariatif, yakni dengan meberikan tugas secara mandiri atau kelompok, membuart suatu karya, melakukan percobaan atau yang paling sederhana memberikan latihan soal di akhir proses pembelajaran. Untuk tingkat yang lebih tinggi, lembaga juga melakukan Penilaian Tengah Semester (PTS) sebagai bentuk penilaian formatif. Sedangkan untuk penilaian sumatif, bentuk yang dilakukan diantaranya Penilaian Akhir Semester (PAS), Penilaian Kenaikan Kelas, Ujian Sekolah dan Ujian Nasional.

\section{PENUTUP}

\section{Kesimpulan}

Berdasarkan analisis yang dilakukan pada kedua lembaga di atas maka dapat disimpulkan bahwa secara umum keempat kawasan teknologi pendidikan yang terdiri dari kawasan penciptaan, penggunaan, pengelolaan dan evaluasi sudah diterapkan di kedua lembaga, yakni di LPBB Solusi Kayumanis dan PKBM Negeri 23 Jakarta. Berdasarkan pengolahan data lembar angket pada kawasan penciptaan LPBB Solusi Kayumanis mendapatkan persentase $77 \%$ dengan predikat baik untuk PKBM Negeri 23 Jakarta mendapatkan $67 \%$ dengan predikat baik. Dari 10 indikator yang ada di kawasan penciptaan 8 indikator sudah diterapkan oleh lembaga. Delapan indikator yang sudah diterapkan adalah penciptaan media dan sumber belajar, penciptaan lingkungan belajar, penciptaan perangkat pembelajaran, analisis karakteristik peserta didik, desain pesan, penciptaan program pembelajaran, kebijakan dan regulasi. Dua indikator yang belum diterapkan adalah penciptaan metode dan strategi pembelajaran.

Berdasarkan pengolahan data lembar angket pada kawasan penggunaan LPBB Solusi Kayumanis mendapatkan persentase $89 \%$ dengan predikat sangat baik untuk PKBM Negeri 23 Jakarta mendapatkan $85 \%$ dengan predikat sangat baik. Dari 8 indikator pada kawasan penggunaan, seluruh indikator telah diterapkan oleh LPBB Solusi Kayumanis dan PKBM Negeri 23 Jakarta. Indikator yang telah diterapkan adalah penggunaan media dan sumber belajar, penggunaan lingkungan belajar, penggunaan perangkat pembelajaran, penggunaan metode dan strategi pembelajaran, penggunaan program pembelajaran, kebijakan dan regulasi.

Berdasarkan pengolahan data lembar angket pada kawasan pengelolaan LPBB Solusi Kayumanis mendapatkan persentase $65 \%$ dengan predikat baik untuk PKBM Negeri 23 Jakarta mendapatkan 79\% dengan predikat baik. Dari 5 indikator pada kawasan pengelolaan, seluruh indikator telah diterapkan oleh LPBB Solusi Kayumanis dan PKBM Negeri 23 Jakarta. Indikator yang telah diterapkan adalah pengelolaan media dan sumber belajar, pengelolaan lingkungan belajar, pengelolaan perangkat pembelajaran, dan pengelolaan personel.

Berdasarkan pengolahan data lembar angket pada kawasan evaluasi LPBB Solusi Kayumanis mendapatkan persentase $88 \%$ dengan predikat sangat baik untuk PKBM Negeri 23 Jakarta mendapatkan 74\% dengan predikat baik. Dari 12 indikator pada kawasan evaluasi, seluruh indikator telah diterapkan oleh LPBB Solusi Kayumanis dan PKBM Negeri 23 Jakarta. Indikator yang telah diterapkan adalah indikator model pengembangan produk, evaluasi media dan sumber belajar, evaluasi lingkungan belajar, evaluasi perangkat pembelajaran, evaluasi personel, evaluasi metode dan strategi pembelajaran, pengukuran acuan patokan, penilaian formatif dan sumatif, analisis pembelajaran, dan evaluasi program.

\section{Saran}

Beberapa hal yang dapat direkomendasikan dari penelitian ini adalah:

1. LPBB Solusi Kayumanis dan PKBM Negeri 23 Jakarta diharapkan dapat melakukan aktivitas penciptaan dengan tahapan yang tepat agar produk yang dihasilkan sesuai dengan kebutuhan.

2. LPBB Solusi Kayumanis dan PKBM Negeri 23 Jakarta perlu memilah dan memilih produk teknologi pendidikan yang tepat dan mengetahui cara penggunaan yang tepat terhadap produk tersebut di dalam proses pembelajaran.

3. LPBB Solusi Kayumanis dan PKBM Negeri 23 Jakarta perlu memilih metodologi manajemen tertentu yang tepat agar pengelolaan yang dilakukan efektif dan efisien.

4. LPBB Solusi Kayumanis dan PKBM Negeri 23 Jakarta diharapkan dapat memulai perencanaan 
evaluasi yang matang agar proses evaluasi yang akan dilakukan dapat menyeluruh.

5. LPBB Solusi Kayumanis dan PKBM Negeri 23 Jakarta dapat mulai mengajukan kerjasama dengan para teknolog pendidikan atau peneliti di tingkat sarjana untuk membuka peluang dan memberikan kontribusi terhadap penerapan kawasan teknologi yang lebih baik.

\section{DAFTAR PUSTAKA}

Aningtiyas, Enggar Sari dkk. (2012). Pengelolaan kursus musik (studi pada lembaga kursus musik 99 Jl. Pattimura Raya Ungaran Kabupaten Semarang). Artikel. Diambil https://journal.unnes. ac.id/sju/index.php/jnfc/artie/view/2803

Arikunto, S. (2006). Prosedur penelitian suatu pendekatan praktek edisi revisi $V$. Jakarta: Rineka Cipta.

Bonastar, Alfa East. (2015). Model pelatihan budidaya lele sebagai upaya pemberdayaan dalam menumbuhkan motivasi berwirausaha pemuda karang taruna di Desa Krete Ranggon Kecamatan Sambeng Kabupaten Lamongan. Artikel. Diambil darihttps://jurnalmahasiswa.

unesa.ac.id/index.php/jurnal-pendidikan-luar-sekolah/ article/view/13219

Budiman, Teguh Hari. (2015). Metode pembelajaran pendidikan non formal TPQ Al Ittihad di Kelurahan Teluk Kecamatan Purwokerto Selatan. Artikel. Diakses dari http://fisip.unsoed.ac.id/ content/

Fahrullah, Reza. (2016). Penggunaan metode pembelajaran discovery learning terhadap peningkatan hasil belajar siswa. Artikel. Diambil dari http:// repository.unpas.ac.id/11445/

Fatiannisa, Rahma. (2017). Manajemen pengelolaan pendidikan nonformal pusat pendidikan bahasa inggris Simpel dan Cepat (SPEC) Borobudur Magelang Jawa Tengah. Artikel. Diambil dari http://digilib.uin-suka.ac.id/26966/

Hanum, Fathia Fairuza. (2015). Evaluasi penerapan pendekatan pembelajaran konstruktivisme di SDIT Permata Bunda Jakarta. Skripsi tidak diterbitkan. Jakarta: Universitas Negeri Jakarta.

Irwan, dkk. (2016). Strategi peningkatan peran pkbm dalam meningkatkan kecakapan hidup masyarakat melalui pendampingan berbasis kearifan lokal di PKBM Provinsi Banten. Artikel. Diambil dari jurnal.untirta.ac.id/index.php/EPlus/article/download/1158/923

Januszweski, A., \& Michael, M. (2008). Educational technology: A definition with commentary. New York: Lawrence Erlbaum Association. Jelita, Irmala. (2015). Evaluasi pelaksanaan program pendidikan nonformal di Panti Asuhan Uswatun
Hasanah Samarinda. Artikel. Diambil dari ps://ejournal. sos.fisip-unmul.ac.id/site/?p=776

Kantun, Sri. (2017). Penelitian evaluatif sebagai salah satu model penelitian dalam bidang pendidikan.

Jurnal Universitas Jember. Artikel. Diakses dari http://jurnal.unej.ac.id/index.php/JPE/article/ view/3809

Miarso, Yusufhadi. (2004). Menyemai benih teknologi pendidikan. Jakarta: Pustekkom bekerjasama dengan Kencana.

Nawipa, Sepo. (2018). Model pelatihan dan pemberdayaan melalui pendidikan non formal berbasis asrama: studi kasus pada Yayasan Pelayanan Antar Budaya melalui Training Indonesians For Transition to Institutional (TITIP) Papua. Artikel. Diambil dari https://ejournal.uncen.ac.id/index. php/JIS/article/view/406

Peraturan Pemerintah No 73 tentang Pendidikan Luar Sekolah. (1971). Diakses dari www.bphn.go.id/ data/documents/91pp073.pdf

Rosfita, Ita. (2017). Penerapan metode pembelajaran Karyawisata pada mata pelajaran sejarah bagi Siswa SMP Homeschooling Prigama Jakarta. Skripsi tidak diterbitkan. Jakarta: Universitas Negeri Jakarta.

Sayori, Paitu. (2015). Pengembangan manajemen pendidikan non formal (penelitian pada lembaga pusat kegiatan belajar masyarakat di Kabupaten Manokwari Provinsi Papua Barat). Artikel. Diambil dari s2ip.apmd.ac.id/file/tesis/pengembangan-manajemen-pendidikan-non-formal.pdf

Seels, B.B., \& Rita, C. R. (1994). Teknologi pembelajaran definisi dan kawasannya (terjemahan). Jakarta: Universitas Negeri Jakarta.

Sugiyono. (2010). Statistika untuk penelitian. Bandung: Alfabeta.

Suprayekti dan Fathia Fairuza. (2017). Penerapan teknologi pendidikan di lembaga persekolahan. Artikel. Diambil dari journal.unj.ac.id/unj/index. php/pip/article/view/7798

Tohari, Entoh. (2011). Pendidikan nonformal dan pengurangan kemiskinan di pedesaan. Artikel. Diambil dari eprints.uny.ac.id/690/1/1002_Yoyon_Suryono_\%28PHK\%29.doc 
Penerapan Teknologi Pendidikan...

16 Jurnal IImiah VISI PGTK PAUD dan Dikmas - Vol. 14 No. 1, Juni 2019 